\title{
Word-Formation Characteristics of Anglicisms in the Russian Slang
}

\author{
Marta Lackova $^{1}$, Olena Hundarenko ${ }^{1}$, Olena Moskalenko ${ }^{2} \&$ Inha Demchenko ${ }^{2}$ \\ ${ }^{1}$ Department of English Language and Literature, Faculty of Humanities, University of Zilina, Univerzitna 8215/1, \\ 01001 Zilina, Slovakia \\ ${ }^{2}$ Department of Foreign Languages, Flight Academy of National Aviation University, Dobrovolskogo, 1, 25005, \\ Kropyvnytskyi, Ukraine \\ Correspondence: Marta Lackova, Faculty of Humanities, University of Zilina, Univerzitna 8215/1, 01001 Zilina, \\ Slovakia. E-mail: marta.lackova@fhv.uniza.sk
}

Received: June 29, 2019 Accepted: July 20, 2019 Online Published: August 26, 2019

doi:10.5539/ijel.v9n5p283 URL: https://doi.org/10.5539/ijel.v9n5p283

\begin{abstract}
The paper deals with characteristics of Anglicisms that operate in the contemporary Russian slang with the emphasis on their word-formation features. The penetration of these lexical units into the Russian language provides a researcher with a linguistically interesting material as the English and Russian languages represent typologically different language systems. To begin with, the research focuses on the origin of the individual word bases and affixes from which the Anglicism instances analysed by us are formed. Moreover, we treat the representation of non-motivated and word-motivated lexemes. At the same time, word-formation means, methods and procedures for the formation of Anglicisms in the Russian slang are taken into account. The above-mentioned lexical units find their word-formation realization within these processes: derivation, composition, compounding, clipping, acronyms, blending, conversion, calques, fusion, univerbization and phonetic mimicry. Additionally, they display differences in onomasiological categories across the studied field. With respect to this, we cover the word-formation features of the processes: word-formation strings, paradigms and nests; word-formation types, onomasiological categories and types of onomasiological categories. The practical utilization of the research is possible in the areas of comparative and applied linguistics and translatology when searching for equivalents of lexical units in typologically different languages. Furthermore, the results of the research are applicable in the methodology of teaching foreign languages.
\end{abstract}

Keywords: Anglicism, Russian slang, lexical unit, word-formation

\section{Introduction}

Social and political changes which have been occurring in the Russian society in the recent decades have been deeply reflected in the vocabulary of the Russian language. The contacts with countries where English is the principal communication language have been reestablished. The inflow of English lexical units has been increased nearly in all spheres of human activities.

When borrowing new words, social, political and cultural aspects are of higher importance than the aspect of genetic relations of languages. The proof of this is also the penetration of lexical units of the English origin into the contemporary Slavic languages (Polozova, 2010).

This linguistic process provides a researcher with a linguistically interesting material that has not been sufficiently analysed neither from linguistic nor methodological points of view. However, there have appeared few dictionaries of slang and research papers of general linguistic (Furdik, 2004; Kachala, 1992; Kollar, 2001) and methodological (Aristova, 1978; Korensky, 1998; Korensky, 2003) character. These studies explore the processes of borrowing new lexical units on the background of communication needs; they do not pay attention to specific linguistic features of loan words. In a similar way, Ondrejovich (1999, p. 79) and Furdik (1993, p. 247) discuss social and political implications that influence mutual contacts of languages in the contemporary society.

Generally speaking, slang cannot be evaluated from normative positions which operate in individual languages; it strives to function in a language as evaluative and expressive nominations which reflect the level of social and cultural awareness of the given language community (Bashtinova, 1997; Habovshtiak, 1993). In connection with this, Mistrik (1998, p. 13) summarizes characteristics of words of English origin in terms of progressivity, language dynamics, terminology and expressivity. 
The quick inflow and penetration of Anglicisms into the Russian slang might cause misunderstandings in common everyday communication when identifying their correct meaning, pronunciation and spelling (Mala, 2003). One of the principal aims of this paper is the contribution to the solution of the semantics aspects of the studied lexical units.

The study of chosen linguistic characteristics of Anglicisms in the Slavic languages has so far attracted the attention only of few researchers. Firstly, Oloshtiak (2002, p. 117) concentrates on phonetic changes which arise when an Anglicism is being assimilated into the contemporary Slovak language; furthermore, Vepyova (2001, p. 51) observes features of Anglicisms in the publicistic style; finally, Hegerova (1999, p. 14) points out that Anglicisms have established a strong position in the scientific prose style. The scientific and general public are only occasionally provided with a detailed analysis of chosen Anglicisms in contemporary Slavic languages, e.g. Horecky (1998, p. 264) discusses the features of the word leasing in the Slovak language. Therefore, we hope to analyse the distinctive linguistic attributes of the lexical units in question; in other words, the aim of this paper is to deal with Anglicisms in the Russian slang with the focus on their word-formation features.

Taking into account the morphological and lexical characteristics of the Russian language (Balaz, 1989) and the above-mentioned extralinguistic implications, we state the hypothesis that the Anglicisms in the contemporary Russian slang follow the basic word-formation principles of the Russian language; at the same time, there appear some irregularities under the influence of the English language. Thanks to our research, we hope to answer these research questions:

1) What are the principal word-word formation processes that Anglicisms in the Russian slang undergo?

2) What are the marginal word-word formation processes that Anglicisms in the Russian slang undergo?

\section{Methodology}

Several both linguistic and non-linguistic methods will be applied when conducting the outlined research. First of all, traditional methods of not only linguistic research — analysis, deduction and summarization — will be utilized together with the knowledge from the linguistic theory. We analyse individual examples of the studied linguistic material from the word-formation perspective; we deduce individual processes that occur when the users of the Russian language employ an Anglicism; we summarize all the processes under their traditional classification. Moreover, the comparative method will be employed when contrasting features of these units in the Russian and English languages.

From the methodological point of view, the research will be done on the confrontation basis with the application of the contrastive attitude with the help of which the specific phenomena will be observed on the word-formation level in the Russian slang system on the English language background.

Standard lexicological methods for the study of the internal structure of the lexical meaning, the prototype and componential analysis, will be exerted when working on the semantic features of individual Anglicisms in the Russian slang. In addition to this, with the help of the distribution method and classification procedure, we will survey the occurrence of Anglicisms in the Russian slang in the linear row.

The foundations for the research corpus will be represented by the dictionaries of slang in the contemporary Russian slang (mainly the online dictionary of Russian youth slang). This paper draws on 10,583-word corpus of slang words that are recorded in the online dictionary; in order to narrow the scope of our study, the words of English origin were elicited, namely 8,371 Anglicisms, the selected items support the immense influence of the English language on the communication among the young users of the Russian language.

\section{Results and Discussion}

Generally speaking, from the point of view of word-formation processes, it is necessary to take into account several aspects that play a key role in creating Anglicisms in the Russian slang. Within all word-formation processes that are summarized below, we focus on the subsequent aspects:

1) the origin of the individual word bases and affixes from which the Anglicism instances analysed by us are formed;

2) the representation of non-motivated and word-motivated lexemes (illustrated within individual word-formation processes);

3) word-formation means, methods and procedures for the formation of Anglicisms in the Russian slang and the word-formation features of that process (illustrated within individual word-formation processes):

(a) word-formation strings, paradigms and nests; 
(b) word-formation types, onomasiological categories and types of onomasiological categories.

To begin with, it is important to note that Anglicisms are productive lexemes from the point of view of word-formation processes, as evidenced by the intra-linguistic indicators of their word-formation potency, such as the frequency of use and their distribution in different communication spheres.

\subsection{The Origin of Individual Components of Anglicisms in the Russian Slang}

When looking at the origin of the individual components of this specific group of Anglicisms in Russian, we are confronted with these combinations:

- lexical units composed only of English word bases / affixes: афтермоб; афтерпати; барби-сайз; гоушоу; холвей; холивар; файербол; прайс-лист; фейсбук (Народ в последний год все больше висит на фейсбуке.); олдскул; саундтрек; сейф моде; стрейт-эйдж; майспейс;

- $\quad$ lexical units composed of English word bases / affixes and Russian word bases / affixes: ангсаб; чикфаер (У тебя не найдется чикфаер?); дебажить; джобать; залочка; засейвить; поюзать; трусмен; лохстайл; офф рот; картмайл; спинномозговик; бойфренд; эпикфейл; снятие хитов; Маски шоу;

- lexical units composed of English word bases / affixes and verbal bases / affixes of classical languages: анисмайль; антифейс; артбук; эпикфейл; телебрейн; технолайдер; каверверсия; киберпанк; микроматч; комплаб; вебмастер; нетикет (Многие посетители этого сайта не знакомы с элементарными правилами нетикета.); спрей-арт; стоп-тайм; стрит-арт; стэнсил-арт; антифлэшмобберы; мегалол;

- lexical units composed of English word bases and French word bases: имиджборда.

The numerous subgroups of the first group define the nouns with the -er suffix, which is very productive in English and retains a strong position as an element of Anglicisms in the Russian slang: геймер; халфер; роллер; слайдер; трекер; тагер; батлхантер; голдфармер; файтер; байкер (Вчера тут банда байкеров проезжала...); дауншифтер; лидер; бэксайдер; тридэшутер.

The compounding of the English word, which has not been adapted by the lexical system of the Russian language with Russian affixes, often of a colloquial nature, can create a parodic or ironic effect:

бутыльбол $($ бутылка + ball $)=$ распитие спиртных напитков; лохмэн $($ лох + man $)=$ неудачник, простак; вирьмейкер $($ вирь + maker $)=$ хакер, занимающийся написанием и запусканием вирусов в компьютерную сеть.

However, most often the English word base is adapted into Russian, so it accepts Russian suffixes and prefixes (see below):

(a) a noun:

герла - гёрла-герлушка-гирла-голда;

айпишник; анимешник; медюшник; хайратник; сидюшник; крезушник;

панкушка; кемперство; интельность; гринписы;_гайда;_батник; океюшки; оки;

b) a verb:

льмаряться; заюзать; разлочить; расшарить; перенайтовать (Пишу сюда, чтобы найти хотя бы где перенайтовать.); прифакиваться; лукать; сейшенить; заасить;

c) a noun and a verb:

френд (Я и мой френд будем в Киеве с этой субботы) - френдлента - френды - зафрендить расфрендить;

d) an adjective:

чипатый; забаненный; олдовый.

\subsection{Word-formation Processes within Anglicisms in the Russian Slang}

The following word-formation processes appear when transferring English lexical units into the Russian slang:

$$
\begin{array}{ll}
\text { - } & \text { derivation - деривация; } \\
\text { - } & \text { composition - композиция; } \\
\text { - } & \text { compounding - образование составных наименований; }
\end{array}
$$




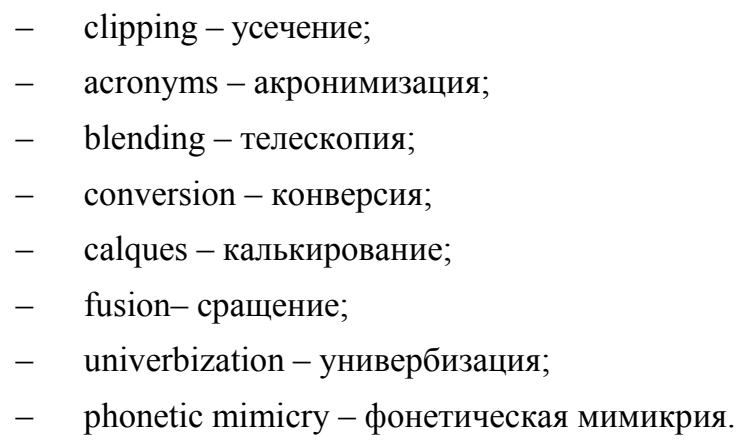

Within the scope of this study, only principal word-formation processes-derivation, compounding, clipping, acronyms and calques - are interpreted in detail. The remaining processes are of low frequency and they represent only marginal phenomena that do not display cahracteristics of general character, we understand them as deviations of the norms of the Russian language.

\subsubsection{Derivation}

Derivation is defined as a way of generating new words from a basic word by changing its morphological structure, especially by adding affixation, distinguishing here the derivation by suffixes or by prefixes, or prefix-suffix and paradigmatic derivation (Mistrik, 1998, p. 33).

Derivation proved to be the most productive word-formation way of creating Anglicisms in the Russian slang as expected, namely suffixation. Prefixation is also significant, but on a smaller scale.

The first parameter that has been the subject of our investigation within derivation is the word-formation that arises in linking word-formation resources (basics and formants) through word-formation processes.

We proceeded from the conception of word formation by J. Furdík (2004, p. 73), who distinguishes two basic types of word-formation units according to the characteristics of the derivative properties and their configurations:

a) identical-root word-formation structures;

b) diverse-root word-formation structures.

Identical-root word-formation structures produce so-called word-formation nests, which are a combination of word-formation rows and word-formation paradigms. The word-formation series is a sequence of motivated words, the following of which is motivated by the previous one, e.g.:

мылть $\rightarrow$ умьгть $\rightarrow$ умыввать $\rightarrow$ умьввальньй $\rightarrow$ умьввальник.

In our case these are the following word-formation strings:

$$
\begin{aligned}
& \text { шарные } \rightarrow \text { расшарить_ } \rightarrow \text { расшаренье } \\
& \text { хак } \rightarrow \text { хакер } \rightarrow \text { хакерский } \\
& \text { прайс } \rightarrow \text { прайсовать } \rightarrow \text { прайсовый } \\
& \text { найт } \rightarrow \text { найтать } \rightarrow \text { найтовать } \rightarrow \text { перенайтовать. }
\end{aligned}
$$

A word-formation paradigm is a set of motives (co-motives) created directly from one motivator, with commotivatives not being motivated, for example:

$$
\text { школа } \rightarrow \text { икольница } \rightarrow \text { икольный } \rightarrow \text { иколярский }
$$

Our research data provide the following instances of word-formation paradigm:

$$
\begin{aligned}
& \text { бутить } \rightarrow \text { бутовый } \rightarrow \text { бутявка } \\
& \text { бэби } \rightarrow \text { бэбик } \rightarrow \text { бэбис } \\
& \text { слич } \rightarrow \text { сличить } \rightarrow \text { спикать } \\
& \text { герла } \rightarrow \text { герлушка } \rightarrow \text { герловый } \\
& \text { гирла } \rightarrow \text { гирловый } \rightarrow \text { гирлица } \\
& \text { фейс } \rightarrow \text { фейсовать } \rightarrow \text { фейсатьій }
\end{aligned}
$$

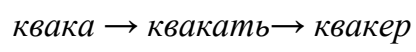

$$
\begin{aligned}
& \text { косплей } \rightarrow \text { косплейщик } \rightarrow \text { косплэйер }
\end{aligned}
$$




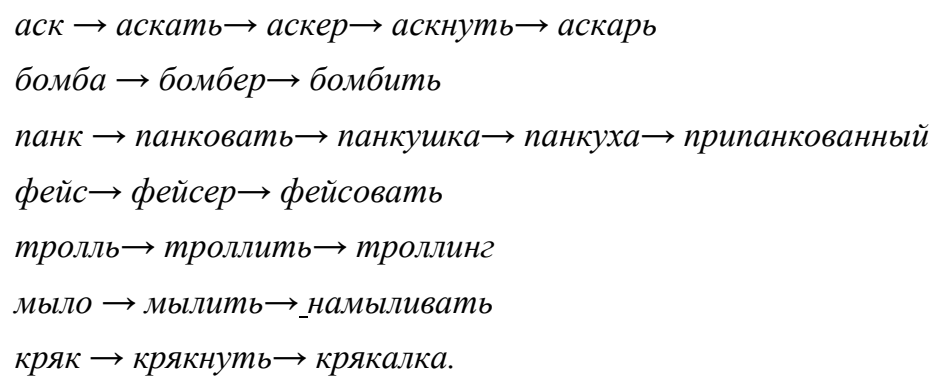

In the Russian slang, we can encounter Anglicisms that originated from a single word base in English and they have formed word-formation nests in Russian. The word-formation nest can also be defined as a coherent set of words with the same root; the real relationship of motivation between them is well felt by members of the linguistic community in the current language:

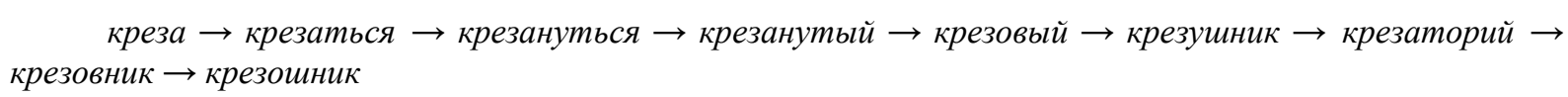

Table 1. Examples of word-formation nests within Anglicisms in the Russian slang

\begin{tabular}{|c|c|c|c|c|}
\hline Word base & Noun & Adjective/adverb & Verb & Interjection \\
\hline \multirow[t]{4}{*}{ юо- } & юзабельность & юзаный & юзать & - \\
\hline & юзер & юзнутый & заюзать & \\
\hline & юзверь & заюзанный & поюзать & \\
\hline & юзверг & & & \\
\hline \multirow[t]{3}{*}{ моб- } & моббер & - & мобить & - \\
\hline & моблик & & мобиться & \\
\hline & мобстер & & & \\
\hline лав- & лаврушка & - & лавить лавкать & - \\
\hline \multirow[t]{3}{*}{ френд- } & - & френдовый & френдить & - \\
\hline & & & зафрендить & \\
\hline & & & расфрендить & \\
\hline \multirow[t]{5}{*}{ дринк- } & дринкер & дринкованный & дринкать & - \\
\hline & дринкало & дринканутый & вылдринкать & \\
\hline & & & задринчить & \\
\hline & & & удринчатъся & \\
\hline & & & надринчаться & \\
\hline \multirow[t]{5}{*}{ хайр- } & хайры & хайрастый & хайраться & - \\
\hline & хайратник & & хайриться & \\
\hline & хайральник & & & \\
\hline & хайровник & & & \\
\hline & хайраст & & & \\
\hline \multirow[t]{4}{*}{ гам- } & погамер & - & гамать гаматься & - \\
\hline & гама & & & \\
\hline & гамовер & & & \\
\hline & гамка & & & \\
\hline \multirow[t]{2}{*}{ толкиен- } & толкиенист & толкиенистский & толкиенуться & - \\
\hline & & толкиенутый & & \\
\hline \multirow[t]{2}{*}{ non- } & nonca & попсово & - & - \\
\hline & попсарня & & & \\
\hline \multirow[t]{3}{*}{ кул- } & кулер & кульный & - & - \\
\hline & кулера & кульно & & \\
\hline & кульман & кульненько & & \\
\hline \multirow[t]{4}{*}{ стеб- } & стебак & - & стебать & - \\
\hline & & & стебаться & \\
\hline & & & стебануть & \\
\hline & & & стебануться & \\
\hline \multirow[t]{2}{*}{ фак- } & фак & зафаканый & прифакиваться & фак \\
\hline & фак-сейшн & & & \\
\hline \multirow[t]{3}{*}{ mon- } & корнер-шопшопинг-терапия & шопинговый & шопинговать & - \\
\hline & шопинг & & & \\
\hline & uоn-myp & & & \\
\hline
\end{tabular}




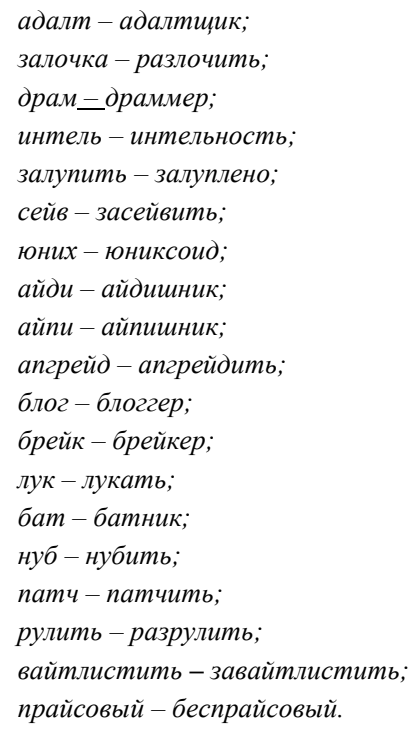

The second type of word-formation, which is specific in terms of derivation within the English language slang, is word-formation based on diverse roots. These derivatives are based on the mutual combination of the onomasiological formant (word-formation base) and onomasiological base (formant) and grouping them into word-formation types, onomasiological categories and types of onomasiological categories.

We define a word-formation type as an open or closed group of word-motivated words that have in common:

a) a type of word-formation base (the same word part of the motivator and the same semantic group within the word class);

b) a word-formation formant that can also be implemented in several phonetic or grammatical variations;

c) a word-formation meaning, i.e., onomasiological structure (Furdík, 2004, p. 83).

We further group the word-formation types into onomasiological categories, which have a common word-formation meaning (onomasiological structure), thus having the same type of word-formation base and the same word-formation meaning. The onomasiological category is thus a hierarchically higher word-formation unit as a word-formation type (Furdík, 2004, p. 86).

We further categorize onomasiological categories into hierarchically higher units - onomasiological categories. Types of onomasiological categories are classified according to the purpose with which the motivated word is formed (change of meaning, variation of meaning, change of syntactic function):

a) mutational type of onomasiological category - in the word-formation act a change in the motivation is realized, whereas the word-class change may or may not occur, e.g. читать $\rightarrow$ читатель;

b) modifying type of the onomasiological category - there is no change of the word species in the word-formation and the motivation differs from the motivator only by one semantic feature (semantic modification), eg. дом $\rightarrow$ домик;

c) transpositional type of onomasiological category - in word-formation, there is a word-class change, but the meaning of motivation is not changed, for example: читать $\rightarrow$ чтение (Furdík, 2004, p. 87).

The overview of individual word-formation means, ways, procedures and units within Anglicisms in the Russian slang is arranged according to the word class to which derived words belong (in concord with their morphological nature) - derivates (substantives, adjectives and verbs). We mention also examples of word-formation non-motivated words in the scope of each word class.

Taking into account numerous word-formation meanings that might occur with individual word-formation formants, we always introduce one word-formation base corresponding to one word-formation meaning and one-word class. 
Table 2. Word-formation motivated nouns created with the help of suffixation

\begin{tabular}{|c|c|}
\hline $\begin{array}{l}\text { Word-formation } \\
\text { formant }\end{array}$ & Word-formation base + word-formation formant \\
\hline$-\mathrm{a}$ & $\begin{array}{l}\text { ганджа, ирка, чика, мандула, колбаса, копипаста, кора, сигна, бага, борда, фронда, пага, пиеса, попса, } \\
\text { месага, мобила, прайма, лайба, лейба, халфа, винда, гайда, гама, жспа, креза, шаровара, нигга, нигрилла, } \\
\text { нода, герла, фанера, фарма, фича, фотожаба, трабла, пулза, сега, квага, квака, гирла, голда, эрвэха, аська, } \\
\text { бейба, экспа, софтина }\end{array}$ \\
\hline$-Я$ & емеля, моня, лабля, попсарня \\
\hline-0 & мыло, мыдло \\
\hline -ник & яблочник, батник, бёзник, хайратник, хардельник, тзиник, струйник, бёздник, экзешник, ТЗшник \\
\hline -шник & айдишник, айпишник, крезушник, тридэшник \\
\hline -ca & чикса \\
\hline -ность & юзабельность, релевантность \\
\hline -щик & адалтщиик, альтернативщиик, эникейщцик, косплейщик \\
\hline -ик & бэбик, варик, флопик, ёжик, бейсик, моблик, жоржик, смайлик, жостик, барсик \\
\hline -ep & $\begin{array}{l}\text { юзер, кудвакер, читер, хаикер, думер, бумер, дайвер, дансер, драммер, дэнсер, клаббер, контрстрайкер, } \\
\text { копирайтер, кул хаикер, репер, рерайтер, рэппер, хипстер, фейсер, фоллаутер, трендсеттер, свингер, } \\
\text { скрапер, скринсейвер, стиллер }\end{array}$ \\
\hline -ист & дэнженист, толкиенист, металлист, толкинист \\
\hline -як & мобиляк, хомяк \\
\hline -явка & бутявка \\
\hline -ка & аддурилка, пойнтовка, таблетка, солярка, корка, мурзилка, каэска, залочка, гамка, крякалка, флэшка \\
\hline -чик & варчик, фуллончик \\
\hline -ство & кемперство \\
\hline -ак & стебак, сервак \\
\hline -ушка & герлушка, лаврушка, кенгурушка \\
\hline -верь & юзверь \\
\hline -ок & движок \\
\hline -ло & двигло \\
\hline -ница & мыльница \\
\hline -юК & сидюк, дивидюк, дидюк, синтюк \\
\hline -ко & ямобилко \\
\hline -op & райтор \\
\hline -арь & аскарь, випарь \\
\hline
\end{tabular}

Examples of nonmotivated nouns in the Russian slang: стафф; флоу; хит; перенсы; панк; байт; крак; лид; гэг; трабл; моб; квест.

From the point of view of diverse base word-formation units we classify the analyzed substantives into these word-formation types:

1st type: identical type of word-formation base (verbal) + identical word-formation formant -верь and identical

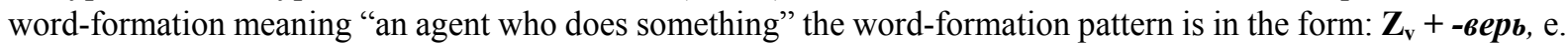
g.: юзверь;

2nd type: identical type of word-formation base (substantive) + identical word-formation formant - $y ш \kappa a$ and identical word-formation meaning "diminutive"; the word-formation pattern is in the form: $\mathbf{B}_{\mathrm{S}}+-\boldsymbol{y} \boldsymbol{и} \boldsymbol{⿰} \boldsymbol{a}$, e. g.: герлушка;

3rd type: identical type of word-formation base (substantive) + identical word-formation formant - $a \kappa$ and identical word-formation meaning "a thing that is used to perform an activity"; the word-formation pattern is in the form: $\mathbf{B}_{\mathbf{s}}$ + -ак, е. g.: стебак;

4th type: identical type of word-formation base (substantive) + identical word-formation formant -cmво and identical word-formation meaning "an existence turned into an object"; the word-formation pattern is in the form: $\mathbf{B}_{\mathrm{s}}+$-ство, е. g.: кемперство;

5th type: identical type of word-formation base (substantive) + identical word-formation formant $-\imath u \kappa$ and identical word-formation meaning "name of the action holder"; the word-formation pattern is in the form: $\mathbf{B}_{\mathbf{s}}+$ -чик, е. g.: варчик;

6th type: identical type of word-formation base (verbal) + identical word-formation formant -явка and identical word-formation meaning "a thing that is used to perform an activity"; the word-formation pattern is in the form: $\mathbf{B}_{\mathbf{v}}$ 
+ -явка, е. g.: бутявка;

7th type: identical type of word-formation base (verbal) + identical word-formation formant $-\Omega$ and identical

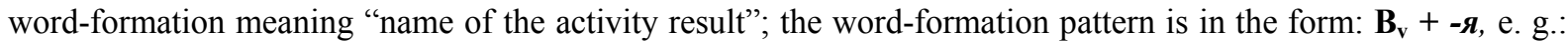
емеля;

8th type: identical type of word-formation base (substantive) + identical word-formation formant $-я \kappa$ and identical word-formation meaning "name according to its origin"; the word-formation pattern is in the form: $\mathbf{B}_{\mathbf{s}}+-\boldsymbol{\Omega} \boldsymbol{\kappa}$, e. g.: мобиляк;

9th type: identical type of word-formation base (substantive) + identical word-formation formant $-u c m$ and identical word-formation meaning "name according to the membership"; the word-formation pattern is in the form: $\mathbf{B}_{\mathbf{s}}+\boldsymbol{- u c m}$, е. g.: дэнженист;

10th type: identical type of word-formation base (verbal) + identical word-formation formant -ep and identical word-formation meaning "an agent who does something"; the word-formation pattern is in the form: $\mathbf{B}_{\mathrm{v}}+\boldsymbol{- e p}$, e. g.: юзер;

11th type: identical type of word-formation base (substantive) + identical word-formation formant $-u \kappa$ and identical word-formation meaning "names according to their purpose"; the word-formation pattern is in the form:

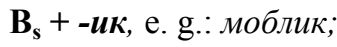

12th type: identical type of word-formation base (substantive) + identical word-formation formant -uик and identical word-formation meaning "an agent who does something"; the word-formation pattern is in the form: $\mathbf{B}_{\mathbf{s}}+$ -щик, е. g.: эникейщик;

13th type: identical type of word-formation base (adjectival) + identical word-formation formant - $щ u \kappa$ and identical word-formation meaning "name of a feature holder"; the word-formation pattern is in the form: $\mathbf{B}_{\mathbf{a d j}}+$ -щик, е.g.: альтернативщик;

14th type: identical type of word-formation base (adjectival) + identical word-formation formant -ность and identical word-formation meaning "a feature turned into an object"; the word-formation pattern is in the form: $\mathbf{B}_{\text {adj }}$ + -ность, е.g.: релевантность

15th type: identical type of word-formation base (substantive) + identical word-formation formant $-c a$ and identical word-formation meaning "name according to the membership"; the word-formation pattern is in the form: $\mathbf{B}_{\mathbf{s}}+-\boldsymbol{c a}$, e. g.: чикса;

16th type: identical type of word-formation base (substantive) + identical word-formation formant -иник and identical word-formation meaning "a person who executes something"; the word-formation pattern is in the form: $\mathbf{B}_{\mathrm{s}}+$-шник, е. g.: айдишник;

17th type: identical type of word-formation base (substantive) + identical word-formation formant $-н и \kappa$ and identical word-formation meaning "a person who executes something"; the word-formation pattern is in the form: $\mathbf{B}_{\mathrm{s}}+$-ник, е. g.: яблочник;

18th type: identical type of word-formation base (substantive) + identical word-formation formant - $a$ and identical word-formation meaning "name of a place"; the word-formation pattern is in the form: $\mathbf{B}_{\mathbf{s}}+\boldsymbol{- a}$, e.g.: жona;

19th type: identical type of word-formation base (verbal) + identical word-formation formant $-o$ and identical word-formation meaning "names of results of activities"; the word-formation pattern is in the form: $\mathbf{B}_{\mathbf{v}}+\boldsymbol{- o}$, e. g.: мылло;

20th type: identical type of word-formation base (verbal) + identical word-formation formant $-\boldsymbol{o} \kappa$ and identical word-formation meaning "names of activity holder"; the word-formation pattern is in the form: $\mathbf{B}_{\mathbf{v}}+\boldsymbol{- o \kappa}$, e. g.: движск;

21 st type: identical type of word-formation base (verbal) + identical word-formation formant $-\kappa a$ and identical word-formation meaning "names of activity means"; the word-formation pattern is in the form: $\mathbf{B}_{\mathbf{v}}+-\boldsymbol{\kappa} \boldsymbol{a}$, e. g.: залочка;

22nd type: identical type of word-formation base (verbal) + identical word-formation formant $-л о$ and identical word-formation meaning "names of activity means"; the word-formation pattern is in the form: $\mathrm{B}_{\mathbf{v}}+-\boldsymbol{- \pi} \boldsymbol{o}$, e. g.: двигло;

23rd type: identical type of word-formation base (verbal) + identical word-formation formant -uцa and identical word-formation meaning "names of activity results"; the word-formation pattern is in the form: $\mathbf{B}_{\mathbf{v}}+\mathbf{- H и ц a}$, e. g.: мыльница; 
24th type: identical type of word-formation base (substantive) + identical word-formation formant $-\kappa o$ and identical word-formation meaning "names according to the purpose"; the word-formation pattern is in the form: $\mathbf{B}_{\mathbf{s}}$ + -ко, е. g.: ямобилко

25th type: identical type of word-formation base (verbal) + identical word-formation formant -op and identical word-formation meaning "a person who executes something"; the word-formation pattern is in the form: $\mathbf{B}_{\mathbf{v}}+\boldsymbol{- o p}$, e. g.: paümop;

26th type: identical type of word-formation base (verbal) + identical word-formation formant - apb and identical word-formation meaning "a person who executes something"; the word-formation pattern is in the form: $\mathbf{B}_{\mathbf{v}}+-\mathbf{a p b}$, е. g.: аскарь.

Individual word-formation types into which substantive derivates - Anglicisms in the Russian slang - have been classified are further assorted into the subsequent onomasiological categories:

1) $\mathbf{B}_{\mathbf{v}}+\mathbf{F}_{\mathbf{s}}$ (verbal word-formation base + substantive word-formation formant with identical word-formation meaning "an agent who does something")

юзверь; юзер; райтор; аскарь (1st type; 10th type; 25th type; 26th type);

2) $\mathbf{B}_{\mathbf{v}}+$ (verbal word-formation base + substantive word-formation formant with identical word-formation meaning "a thing that is used to perform an activity")

бутявка; залочка; двигло (6th type; 21st type; 22nd type);

3) $\mathbf{B}_{\mathbf{v}}+\mathbf{F}_{\mathbf{s}}$ (verbal word-formation base + substantive word-formation formant with identical word-formation meaning "names of activity results")

емеля; мыло; мыльница (7th type; 19th type; $23^{\text {rd }}$ type);

4) $\mathbf{B}_{\mathbf{s}}+\mathbf{F}_{\mathbf{s}}$ (substantive word-formation base + substantive word-formation formant with identical word-formation meaning "names according to the membership")

дэнженист; чикса (9th type; 15 th type);

5) $\mathbf{B}_{\mathbf{s}}+\mathbf{F}_{\mathbf{s}}$ (substantive word-formation base + substantive word-formation formant with identical word-formation meaning "a person who executes something")

айдишник; яблочник (16th type; 17th type);

6) $\mathbf{B}_{\mathbf{s}}+\mathbf{F}_{\mathbf{s}}$ (substantive word-formation base + substantive word-formation formant with identical word-formation meaning "names according to their purpose")

моблик; ямобилко (11th type; 24th type).

Moreover, the above-mentioned onomasiological categories are classified into these units - types of onomasiological categories:

1) Mutational type of an onomaziological category (deverbatives)

A Word-formation meaning "an agent who does something"

B Word-formation meaning "a thing that is used to perform an activity"

C Word-formation meaning "names of activity results"

2) Mutational type of an onomaziological category (desubstantives)

A Word-formation meaning "names according to the membership"

B Word-formation meaning "a person who performs an activity"

C Word-formation meaning "names according to their purpose"

Table 3. Word-formation motivated adjectives created with the help of suffixation

\begin{tabular}{ll}
\hline Word-formation formant & Word-formation base + word-formation formant \\
\hline -овый & гирловый, пипловый, прайсовый, квадовый, флэтовый, крезовый, гуёвый, беспрайсовый \\
-ный & форевный, дефолтный, тюненый, шарный, маздайный, трушный \\
-альный & Инфернальный \\
-ёвый & труёвый, сказёвый \\
-тый & Крезанутыий \\
-ячий & Босячий \\
\hline
\end{tabular}


Examples of non-motivated adjectives in the Russian slang: биговый, олдовый, лонговый, сексабельный, кульный.

From the point of view of diverse base word-formation units we classify the analyzed adjectives into these word-formation types:

1st type: identical type of word-formation base (substantive) + identical word-formation formant -овыц̆ and identical word-formation meaning "evaluation of the subject"; the word-formation pattern is in the form: $\mathrm{B}_{\mathbf{S}}+$ -овый, е. g.: пипловыци;

2nd type: identical type of word-formation base (adverbial) + identical word-formation formant -ный and identical

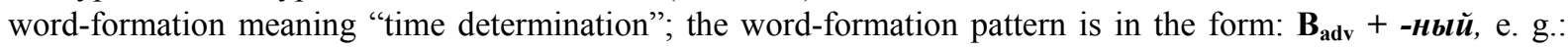
форевный;

3rd type: identical type of word-formation base (substantive) + identical word-formation formant $-\mu b i \check{u}$ and

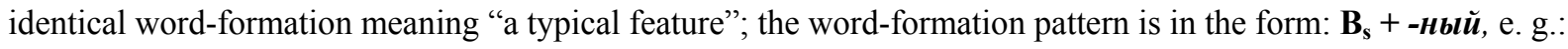
дефолтный;

4th type: identical type of word-formation base (substantive) + identical word-formation formant -альный and identical word-formation meaning "a broad relationship"; the word-formation pattern is in the form: $\mathbf{B}_{\mathbf{s}}+$-альный е. g.: инфернальный;

5th type: identical type of word-formation base (substantive) + identical word-formation formant -ëвblŭ and identical word-formation meaning "a typical feature"; the word-formation pattern is in the form: $\mathbf{B}_{\mathbf{s}}+-\ddot{e} \boldsymbol{b} \boldsymbol{b} \boldsymbol{\text { ŭ }}$, е. g.: труёвый;

6th type: identical type of word-formation base (substantive) + identical word-formation formant -нymbiй and identical word-formation meaning "a prominent feature"; the word-formation pattern is in the form: $\mathbf{B}_{\mathbf{s}}+-\boldsymbol{m b l u}$, e. g.: крезанутый;

7th type: identical type of word-formation base (substantive) + identical word-formation formant -ячий and

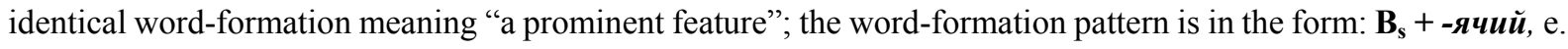
g.: босячий.

Individual word-formation types into which adjectival derivates - Anglicisms in the Russian slang - have been classified are further assorted into the subsequent onomasiological categories:

1) $\mathbf{B}_{\mathbf{s}}+\mathbf{F}_{\text {adj }}$ (substantive word-formation base + adjectival word-formation formant with identical word-formation meaning "a typical feature")

дефолтный; труёвый; (3rd type; 5th type);

2) $\mathbf{B}_{\mathbf{s}}+\mathbf{F}_{\text {adj }}$ (substantive word-formation base + adjectival word-formation formant with identical word-formation meaning "a prominent feature")

крезанутьй; босячий; (6th type; 7th type).

Moreover, the above-mentioned onomasiological categories are classified into these units - types of onomasiological categories:

1) Mutational type of an onomaziological category (desubstantives)

A Word-formation meaning "a typical feature"

B Word-formation meaning "a prominent feature"

Prefixation as one of the derivative word-formation processes finds its realization when creating adjectives within Anglicisms in the Russian slang to a lesser extend than suffixation.

Table 4. Word-formation motivated adjectives created with the help of suffixation and prefixes

\begin{tabular}{ll}
\hline $\begin{array}{l}\text { Word-formation } \\
\text { formant }\end{array}$ & Word-formation formant + word-formation base + word-formation formant \\
\hline за- & засеренный, зафаканый, заюзанный \\
у- & Удринченныцй \\
при- & Припанкованныц̆ \\
бес- & Беспрайсовый \\
\hline
\end{tabular}


All word-formation bases of these adjectives are adjectival, we deal with deadjectives, while prefixation is utilised when making the meanings of adjectives stronger or weaker. The strengthening and weakening of adjectives belong to modifying adjectival categories, the source adjective is just semantically modified.

Table 5. Word-formation motivated verbs created with the help of suffixation

\begin{tabular}{|c|c|}
\hline $\begin{array}{l}\text { Slovotvorný } \\
\text { formant }\end{array}$ & Slovotvorný základ + slovotvorný formant \\
\hline -кать & Лавкать \\
\hline -ать(ся) & $\begin{array}{l}\text { гамать, гаматься, найтать, джсобать, лахать, лукать, скипать, стебать, стебаться, прайсовать, } \\
\text { качаться, квакать, кулёмать }\end{array}$ \\
\hline -ять(ся) & Лымаряться \\
\hline -еть & Фанатеть \\
\hline -овать & найтовать, зиповать, пинговать, фейсовать, панковать \\
\hline -нуть(ся) & толкиенуться, кликнуть, крякнуть, апнуть, хильнуть \\
\hline -ануть(ся) & иинкануть, стебануть, стебануться, крезануться, сендануть \\
\hline -ить(ся) & $\begin{array}{l}\text { апгрейдить, асить, бомбить, гуглить, флудить, дебажить,_жазить, лавить, рарить, ребудить, рулить, } \\
\text { сейшенить, спамить, стопить, стрейфить, фанить, мобить, мобиться, мониторить, мылить, пиксить, } \\
\text { плэить, клубиться, ксерачить, ксерить, глючить, апрувить, биндить, вайтлистить, капсить, } \\
\text { копирайтить, эникеить, нубить, патчить, регить, региться, рерайтить, френдить, троллить, сендить, } \\
\text { бирить, хардрочиться }\end{array}$ \\
\hline
\end{tabular}

Examples of non-motivated verbs in the Russian slang: юзать, килять, аскнуть, бутить, вейкапиться, хундерстандить аскать, бэкапить, жарить, хайдить, лайкать.

From the point of view of diverse base word-formation units we classify the analyzed substantives into these word-formation types:

1st type: identical type of word-formation base (verbal) + identical word-formation formant -кать and identical word-formation meaning "diminutiveness"; the word-formation pattern is in the form: $\mathbf{B}_{\mathbf{v}}+\boldsymbol{- \kappa a m b}$, е. g.: лавкать;

2nd type: identical type of word-formation base (substantive) + identical word-formation formant - $a m b(c \Omega)$ and identical word-formation meaning "to perform an activity which is named by the motivant"; the word-formation pattern is in the form: $\mathbf{B}_{\mathbf{S}}+\boldsymbol{- a m b}(\boldsymbol{c a})$, e. g.: zaмamb;

3rd type: identical type of word-formation base (substantive) + identical word-formation formant -яmьcя and identical word-formation meaning "to act in the way which is named by the motivant"; the word-formation pattern is in the form: $\mathbf{B}_{\mathbf{s}}+$-яться, е. g.: лымаряться;

4th type: identical type of word-formation base (substantive) + identical word-formation formant -emb and identical word-formation meaning "to act in the way which is named by the motivant"; the word-formation pattern is in the form: $\mathbf{B}_{\mathbf{s}}+\mathbf{- e m b}$, e. g.: фанатеть;

5th type: identical type of word-formation base (substantive) + identical word-formation formant -oвamb and identical word-formation meaning "to have an action relationship to the motivant as the object of the action"; the word-formation pattern is in the form: $\mathbf{B}_{\mathbf{s}}+$ - овать, е. g.: найтовать;

6th type: identical type of word-formation base (verbal) + identical word-formation formant - нуть $($ ся) and identical word-formation meaning "perfectivization"; the word-formation pattern is in the form: $\mathbf{B}_{\mathbf{v}}+\boldsymbol{- \mu y m b}(\mathbf{c r})$, e. g.: кликнуть;

7th type: identical type of word-formation base (verbal) + identical word-formation formant - ануть (cя) and identical word-formation meaning "perfectivization"; the word-formation pattern is in the form: $\mathbf{B}_{\mathbf{v}}+\mathbf{- a h y m b}(\boldsymbol{c a})$, е. g.: стебануть;

8th type: identical type of word-formation base (substantive) + identical word-formation formant $-u m b(c r)$ and identical word-formation meaning "to perform an activity which is named by the motivant"; the word-formation pattern is in the form: $\mathrm{B}_{\mathbf{s}}+\boldsymbol{- u m b}(\boldsymbol{c} \boldsymbol{g})$, е. g.: мониторить;

Individual word-formation types into which verbal derivates - Anglicisms in the Russain slang - have been classified are further assorted into the subsequent onomasiological categories:

1) $\mathbf{B}_{\mathbf{s}}+\mathbf{F}_{\mathbf{v}}$ (substantive word-formation base + verbal word-formation formant with identical word-formation meaning "to perform an activity which is named by the motivant") 
гамать; мониторить; (2nd type; 8th type);

2) $\mathbf{B}_{\mathbf{s}}+\mathbf{F}_{\mathbf{v}}$ (substantive word-formation base + verbal word-formation formant with identical word-formation meaning "to act in the way which is named by the motivant")

льммаряться; фанатеть; (3rd type; 4th type);

3) $\mathbf{B}_{\mathbf{s}}+\mathbf{F}_{\mathbf{v}}$ (substantive word-formation base + verbal word-formation formant with identical word-formation meaning "perfectivization")

кликнуть; стебануть; (6th type; 7th type).

Moreover, the above-mentioned onomasiological categories are classified into these units - types of onomasiological categories:

1) Mutational type of an onomaziological category (desubstantives)

A Word-formation meaning "to perform an activity which is named by the motivant"

B Word-formation meaning "to act in the way which is named by the motivant"

2) Mutational type of an onomaziological category (deverbatives)

A Word-formation meaning "perfectivization".

Similarly to adjectives, prefixation as one of the derivative word-formation processes finds its realization when creating verbs within Anglicisms in the Russian slang to a lesser extend than suffixation.

Table 6: Word-formation motivated verbs created with the help of suffixation and prefixes

\begin{tabular}{ll}
\hline $\begin{array}{l}\text { Word-formation } \\
\text { formant }\end{array}$ & Word-formation formant + word-formation base + word-formation formant \\
\hline на- & Намыливать \\
при- & Прифакиваться \\
пере- & Перенайтовать \\
за- & залупить, засейвить, зафрендить, захайдить, залогиниться, забанить, заюзать, завайтлистить, \\
& засупендить, зафачить \\
раз-/рас- & разлочить, расфрендить, расиарить, разрулить \\
по- & поюзать, пофиксить \\
про- & Пропиариться \\
\hline
\end{tabular}

All word-formation bases of these verbs are verbal, we deal with deverbatives, while prefixation is utilized when creating aspectual forms of verbs. Creating the perfective aspect belongs to modifying verbal categories, the source verb is only semantically modified.

At the end, it is possible to add that from the point of view of the onomasiological structure of the word (we take into account mutual diversity or identity of the onomasiological base and onomasiological formant) one finds these options:

a) diverse onomasiological base + identical onomasiological formant:

блюрей - блютуз (Лично я пользуюсь блютузом - уже пять лет);

брейкбит - брейкданс;

брейн полесский - брейн-нокаут - брейн-ринг - брейнбол-брейнцион;

хипан - хиппань - хиппи - хипьё;

ФМ-акиия - ФМ-движение - ФМ-ресурс - ФМ-символика;

кул - кул хацкер - кулёма - кулёмать - кулер - кулхацкер - кульман - кульненько - кульно;

моб-арт -моб-игра -моб-тур - моб-туризм - моббер - мобить -мобиться - моблик-мобстер мобхаус - кино-моб - имоб - экстрим-моб - СМС-моб - флэщмоб - фото-моб - социальный моб спант-моб - официиальный моб;

b) identical onomasiological base + diverse onomasiological formant:

юзать - гамать - лайкать - лахать;

найтовать - панковать; 
крезануться (Крезануться можно, если въехать в эту шизу.) - крякнуть;

байкер - хакер - драйвер - ламер - лузер - кракер;

хайратник-хардельник.

\subsubsection{Formation of compounds}

In the Russian slang, we have found compounds - the process of naming by using several words (Mistrik, 1998, p. 250) which have the following structure:

1) Anglicism / Anglicisms + word / words of Russian origin: бельй каталог сайтов (Бельий каталог сайтов это каталог, не требуюший установления обратной ссылки на страницах включенного в каталог сайта.); валюме убавить; вопрос брейновский; казуальные игры; пиринговые сети; флэи группа;

2) Anglicism / Anglicisms + word / words of classical origin: агрессив инлайн; лав сим; Лив Экин; хакерская этика; хит виртуальньй; хит реальнылй; дисторт реалити; системный пипл; тик в квадратике; флэммоб акция;

3) Anglicism + Anglicism: гамать в писюк (Чем занимаешься? - Гамаю в писюк); фаст флоу; тру эмо.

The above- mentioned compounds are of the subsequent character:

1) congruent (adjective + noun): бельлй хайратник;

2) non-congruent (non-attribute, verb + subject): качать версию.

In accordance with the structural aspect, we have divided the compounds into:

1) substantive, composed of two nouns: рейтинг вопроса; рейтинг команды; the second noun is from the syntactic point of view a mismatch, most often in the genitive, but it can also exist in another form;

2) substantive, composed of adjective and noun: файлообменные сети;

3) substantive composed of part and noun: pacmapeные pecypcbl.

Three and multi-word associated names - Anglicisms in the Russian slang - can act as decription of original English acronyms.

\subsubsection{Clipping}

Many Anglicisms are expressed in the Russian language in the abbreviated form of the original English lexemes:

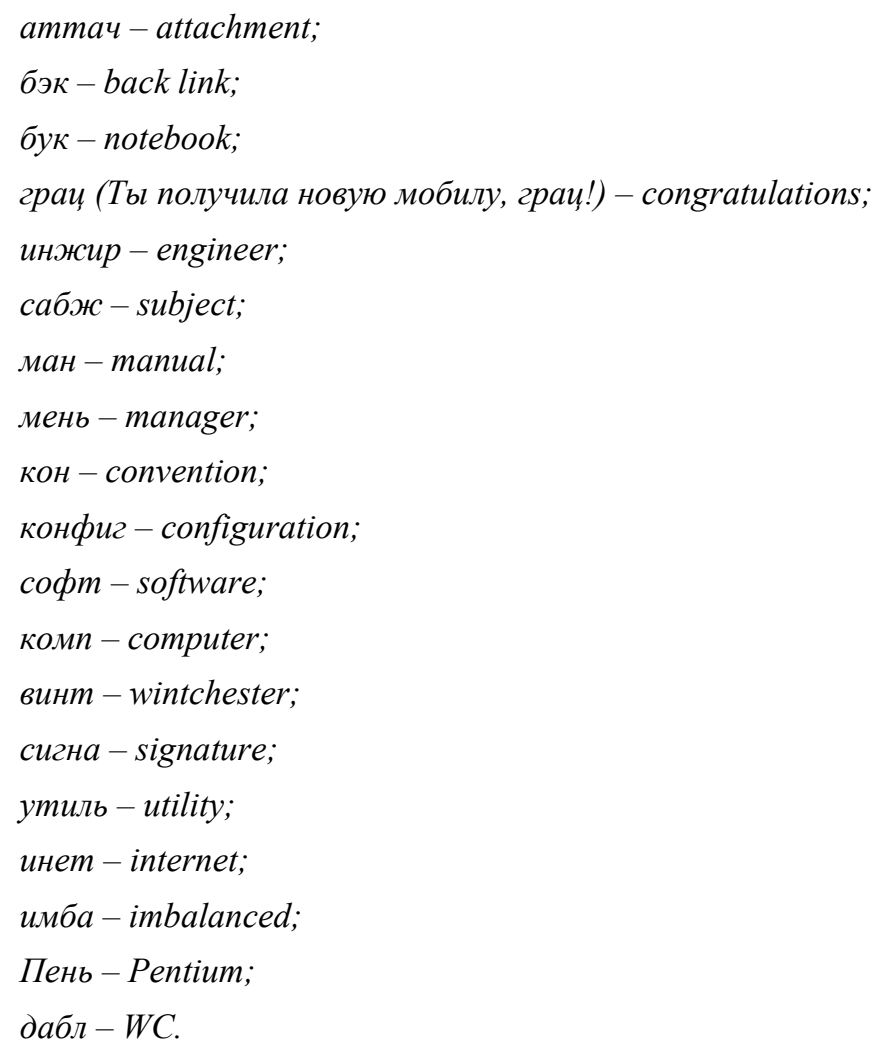


In these cases, it is not possible to talk about the regularity of the creation of shortened lexemes, as the initial, central and final parts of the lexemes are shortened in the Russian language. On the other hand, the terminal part of the original English word is mostly eliminated. The original English allomorphs are often ignored during the word-formation process.

A short form of a word often exists along with a full shape: ник - никнейм; ноут - нотебук.

We can also observe cases where the modified form of the English phrase does not carry the same meaning: айкетч is used in meaning „приблизительно 2-х секундная заставка в середине аниме-сериала, обозначающая начало и окончание рекламной вставки при показе сериала по телевидению“ compared to the original meaning catch the eye „попасться на глаза“.

Numerous Anglicisms in the Russian slang are abbreviations - steady word units that have been created by shortening a word or phrase (Mistrik, 1998, p. 184).

Within this specific group, we distinguish them based on the following criteria:

1) orthographic form adopted in Russian:

a) their written form in Russian is according to the original English spelling:

АДНД - AD\&D;

$\Phi M-F M-$ Flash Mob;

$A M B-A M V-$ Anime Music Video;

$O B A-O V A-O A V-$ Original Video Animation;

$\Pi M-$ Private Messages;

ОНА - original net animation - оригинальная сетевая анимация;

Ocm - original sound track (У тебя, случайно, нет остов от Matrixa?);

Cepn - SERP - Search Engine Results Page;

Ceо - SEO - Search Engine Optimization - оптимизация для поисковых машин;

b) their written form in Russian is according to the original English pronunciation:

$A \check{u} \partial u-I D$;

Айпи $-I P$;

Пиар $-P R$;

СиДи Драма-CD Drama;

Писиай-PCI-Peripheral component interconnесt- внешняя связь с периферийными компонентами;

c) two forms - by pronunciation in Russian / English and by original English spelling / transcription in Cyrillic:

Лыжи - эл джи - LJ - live journal;

ДНД-Дээндэ-D\&D;

ББ-Бай-бай - bye bye;

Xуис-Xуйc - WHOIS - who is;

Дэ-энд-дэ - ДНД (Существуют книги в стиле ДНД, их выпускает фирма ...) - Dungions and dragons;

Аська-ICQ;

Wona - Z Object Publishing Environment;

Лвл-level;

Оля - OLE - Object Linking and Embedding - связи и вложения объектов.

2) word-formation form adopted in Russian:

a) initial letters of words (called инициальные аббревиатуры):

Биос - BIOS - Basic Input-Output System;

ГПУ - Graphics Proccesing Unit; 
ИСA - Image Song Album;

ГФM - GFM - Global Flash Mob;

Гуй GUI-Graphical User Interface;

Ирда IrDA - Infrared Data Association;

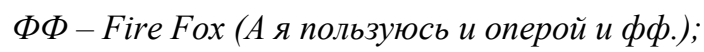

ПР - Page Rank - ранг страницьь;

PCC-Really Simple Syndication;

Bun - Very Imporatant Person;

KC-Counter Strike;

Лэвэ - liberal values;

b) initial syllables of words (called слоговые аббревиатуры):

косплей-cosplay - costume playing;

фанфик-fun fiction;

вирпил (Вирпиль уже собрались на встречу в реале.) - virtual pilot - виртуальный пилот;

нодедифф - noddiff - nodelist different;

сега - selfguided - сам себе гид;

юпик-user picture;

c) word combination + full word form combination (called слогово-словесные аббревиатуры):

пруфпик-proof picture;

камхоринг-camera whore;

d) combination of the initial syllable of the word + the first letter of the word:

Hyn-new player.

The special group is formed by the abbreviations that originated from the initial letters of the English phrases:

АФАИК - Афаик_(Афаик этот девайс просто надо выключить - AFAIK - as far as I know;

AKA - AKA - Also Known As;

Визивиг - WYSIWYG - What You See Is What You Get (Визивиг часто используется редакторами веб-страниц.);

ИМХО - IMHO - in my humble opinion;

C3OT-sorry za offtopic;

Aфк-away from keyboard;

БэРэБэ - be right back;

Диавай-DIY-Do It Yourself;

Дom - Damage Over Time;

PTФМ - RTFM - Read The following (fucking, fine) Manual - Прочти эту подробную (чёртову, хорошую) инструкичию;

Рофл-ROFL - Rolling on the Floor Laughing - катаюсь по полу от смеха;

OMГ-Oh my God - O боже!

Акаб - ACAB - All Cops Are Bastards.

One of the features of the English abbreviations is that they can represent multiple phrases and thus multiple meanings. We also encounter this phenomenon in a group of abbreviations - Anglicism in the Russian slang:

ГГ-good game - хорошая игра - Great Game alebo ГГ- главгер;

$\Pi$ - Page Rank alebo Public Relation. 


\subsubsection{Acronyms}

Acronyms - a group of abbreviations named from the initial voices or syllables (Mistrik, 1993, p. 57), which are read as one word - also find their place in the Russian slang of English origin: тебя;

Аська (Аська-интернет-пейджер ICQ.или твой личный номер в сети ICQ.) - i seеk уои - я ищу

Эрвэха - RW (Read/Write);

сказёвый - SCSI - Small Computer System Interface, букв. интерфейс мальх компьютерных систем;

Винтукей - Win $2 k$;

Ирка - IRC - Internet Relay Chat;

Жопорез - GPRS - General Packet Radio Service - пакетная радиосвязь общего пользования).

Abbreviations are still to be mentioned - acronyms consisting of letters and numbers based on the pronunciation of letters or numbers: $4 U-$ for you.

\subsubsection{Calques}

An extensive group of Anglicisms in the Russian language originated on the basis of calculus (the process of translating a word from a foreign language). Mistrik (1983, p. 55) distinguishes between semantic and word-formation calques.

Semantic calques are defined as names that have been translated by word-by-word system. Examples of semantic calques of Anglicisms in the Russian slang:

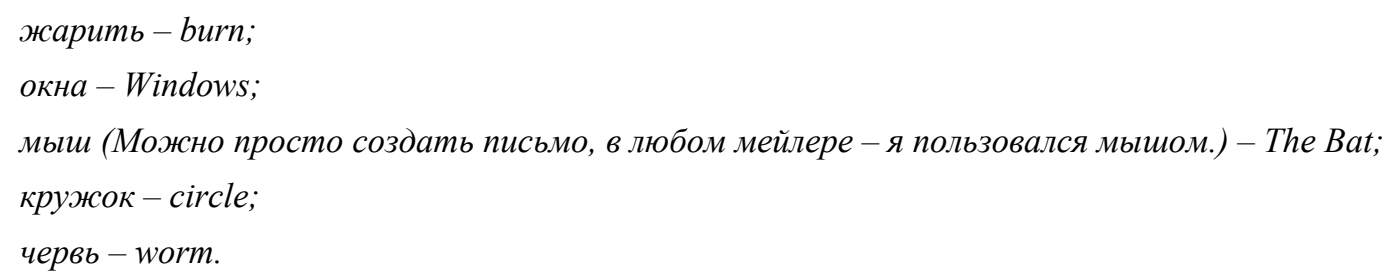

On the other hand, word-formation calques are defined as denominations in which the entire morphematic or word-formation structure of a foreign word is taken over and translated.

Examples of word-formation calques of Anglicism in the Russian slang:

голубой зуб - blue tooth;

Всемирная Паутина - World Wide Web;

девииа без презента - device not present;

девица не готова - device not ready;

дохлая утка-dead duc;

длиннокот - longcat;

зеркало сайma - site mirror;

засеренный-greyed-out;

материнка-motherboard;

межделмаш - International Business Machines - международные деловые машины;

огнелис (лисовод) - FireFox;

мелкомягкий-Microsoft;

мелкософт - Microsoft;

осёл-ослик ИЕ-e-Donkey-e-mule;

морда-face page;

яблочник-Apple;

поисковый паук - search spider;

отложить яйи̧о - lay away eggs; 
три пальцุа - three fingers salute - комбинащчия клавиш Ctrl-Alt-Del,

сделать сладкую заднииу - make sweet ass.

\section{Conclusion}

When studying the specific group of Anglicisms in the Russian language it is crucial to realize that not all lexical units have undergone an analogical process of adaptation in the given time period. In other words, the process of the adaptation is not homogenous. At this time, it is not possible to state strict rules of Anglicisms functioning in the Russian slang. Arising from the material corpus which is mapping the given space we can only point certain tendencies of the integration and adaptation processes.

Regarding the stated hypothesis, it has been proved; major word-formation processes (derivation, compounding, clipping, acronyms and calques) that are realized in the Russian language find their materialization also within the scope of the new lexical units taken from the English language; on the other hand, there occur numerous spelling and pronunciation irregularities (within marginal processes of composition, blending, conversion, fusion, univerbization and phonetic mimicry) that might make the communication more troublesome. In addition to this, our findings are in concord with the theoretical knowledge as it is outlined in Introduction.

In conclusion, we would like to point out that the analysis of word-formation processes within the studied area is not based on an absolute completeness of the lexical material as the word stock in contemporary languages represents an open system which is being developed and enriched by new lexical units; we understand this fact as a certain limitation.

Furthermore, the Anglicisms in the Russian slang are to be elaborated from the phonetic, orthographic, morphological, lexicological, semantic, sociolinguistic, psycholinguistics and etymological perspectives.

The study is addressed to researches who carry out their activities within the scope of the English and Russian languages. Moreover, the practical utilization of the paper is seen in the following areas:

- comparative and applied linguistics;

- translatology (searching of equivalents of in typologically different languages);

- methodology of teaching foreign languages (teaching mainly at universities when studying two or more languages).

\section{References}

Aristova, V. M. (1978). Anglo-russkie yazyikovyie kontaktyi: anglizmyi v russkom yazyike. Leningrad: Izdatel'stvo Leningradskogo universiteta.

Balaz, G. et al. (1989). Sovremennyiy russkiy yazyik v sopostavlenii so slovatskim. Morfologiya. Bratislava: SPN.

Bashtinova, G. (1997). Mother Tongue Interference at the Lexical Level: An Introduction to the English-Slovak "Faux Amis". Philologica, XLVI, 69-79.

Furdik, J. (1993). Slovotvorna motivacia a jej jazykove funkcie. Levocha: Modry Peter.

Furdik, J. (2004). Slovenska slovotvorba (Ed. M. Oloshtiak). Preshov: Nauka.

Habovshtiak, A. (1993). Zo slovensko-slovanskych lexikylnych vztahov. Bratislava: VEDA.

Hegerova, K. (1999). Anglicizmy a internacionalizmy v technickych normach. Kultura Slova, 1, 13-18.

Hochel, B. (1993). Slovnik slovenskeho slangu. Bratislava: HEVI.

Horecky, J. (1998). Miesto a funkcia slova lizing (leasing) v slovencine. Kultura Slova, 5, 264-268.

Kachala, J. (1992). Slovo manazment v slovenchine. Kultura Slova, 5-6, 155-159.

Kollar, D. (2001). Suchasne trendy v preberane cudzich slov (na ruskom a slovenskom materiali). Slavica Slovaca, 2, 108-113.

Korensky, J. (1998). Metodologicke problemy zkoumani promen souchasnych slovanskych jazyku. Jazykovedny Chasopis, 1-2, 27-33.

Korensky, J. (2003). Internacionalizace souchasnych slovanskych jazyku - moznost nebo nutnost? Jazykovedny Chasopis, 1-2, 7-11.

Mala, E. (2003). Substantivne anglicizmy a ich analyza v ruskom jazyku. Banska Bystrica: UMB.

Mistrik, J. (1983). Moderna slovencina. Bratislava: SPN. 
Mistrik, J. (1993). Encyklopedia jazykovedy. Bratislava: Obzor.

Mistrik, J. (1998). Lingvisticky slovnik. Bratislava: SPN.

Oloshtiak, M. (2002). Transfonemizacia v kontaktovom vztahu anglichtina - slovenchina. Slovenska rech. 2, 111126.

Ondrejovich, S. (1999). Slovenchina v kontaktoch a konfliktoch s inymi jazykmi. Bratislava: Veda.

Polozova, S. V. (2010). Inoyazyichnyie zaimstvovaniya kak istochnik popolneniya leksiko-frazeologicheskogo sostava sovremennyih russkih zhargonov. Retrieved from http://www.vestnik.vsu.ru/pdf/lingvo/2008/03/2008_03_16.pdf

Slovar sovremennogo molodezhnego slenga. Retrieved from http://teensalng.su/

Vepyová, Z. (2001). Anglicizmy v slovenskej publicistike. Acta Facultatis Paedagogicae Universitatis Tyrnaviensis. Trnava, 49-51.

\section{Copyrights}

Copyright for this article is retained by the author, with first publication rights granted to the journal.

This is an open-access article distributed under the terms and conditions of the Creative Commons Attribution license (http://creativecommons.org/licenses/by/4.0/). 